observed an appreciable increase in serum cholesterol at the end of several weeks whereas we measured a serum cholesterol level three times as high as theirs at the end of three-and-a-half years. Population studies, ${ }^{4}$ furthermore, clearly show the close correlation between serum cholesterol and the prevalence of ischaemic heart disease.

We therefore concluded that regular consumption of many eggs over a long time is harmful, a fact which doctors should remember when advising people about weight reduction in order to prevent coronary heart disease. This is particularly important as some nonscientific magazines and journals have published slimming diets for overweight people, recommending 10 or more eggs a day.

${ }^{1}$ Mann, G V, Andrus, S B, Fournal of Laboratory and Clinical Medicine, $1956,48,533$.

${ }^{2}$ Gresham, G A, et al, British fournal of Experimental Pathology', 1965, 46, 94.

${ }^{3}$ Connor, W E, Hodges, R E, and Bleiler, R E, fournal of Clinical Investigation, 1961, 40, 894 .

${ }^{4}$ Kannel, W B, et al, Annals of Internal Medicine, 1964, 61, 888.

Department of Internal Medicine, University of Innsbruck, Innsbruck, Austria

H P RHOMBERG, MD, senior resident physician

H BRAUNSTEINER, MD, professor of medicine and head of department

\section{Hydrogen ion infusion for treating severe metabolic alkalosis}

Conventional treatment of metabolic alkalosis consists of administering sodium, potassium, and chloride, but the response is slow. Infusions of hydrogen ion produce a rapid improvement, as in the case reported here, and represent a more physiological approach to the condition.

\section{Case report}

A 53-year-old woman presented with a 24-hour history of profuse vomiting associated with carpopedal spasm and ensuing drowsiness and dysphagia. Previously she had suffered from intermittent anorexia without indigestion or vomiting and chronic bronchitis with exertional dyspnoea of one year's standing. She had had no antacid treatment.

On admission she was marasmic, dehydrated, and delirious, making choreiform movements. Blood pressure was $100 / 60 \mathrm{~mm} \mathrm{Hg}$ and pulse rate 100 beats/min (atrial fibrillation). A succession splash was heard, and residual gastric volume on aspiration was $150 \mathrm{ml}$. Central venous pressure was $-5 \mathrm{~cm} \mathrm{H}_{2} \mathrm{O}$.

Electrolyte and blood gas levels on admission were compatible with severe vomiting secondary to pyloric stenosis (later confirmed by gastrografin meal). She was given $375 \mathrm{mmol}$ ( $375 \mathrm{mEq}$ ) of sodium and chloride and $128 \mathrm{mmol}$ $(128 \mathrm{mEq})$ of potassium over 18 hours without improvement of her alkalosis (see table).

Because of evidence of failing renal function $300 \mathrm{mmol}(300 \mathrm{mEq})$ of hydrogen ion was infused over 18 hours as $0 \cdot 1-\mathrm{M}$ hydrochloric acid via a central vein, the amount being calculated from her body weight $(40 \mathrm{~kg})$ and her chloride deficit (see below). A considerable clinical and biochemical improvement followed. Involuntary movement ceased, and she became responsive to her name and aware of her surroundings.

Nutrients were given intravenously with the aim of surgical intervention; but she died after 11 days, having developed an overwhelming bronchopneumonia. Necropsy confirmed bronchopneumonia and pyloric stenosis due to benign fibrosis.

\section{Discussion}

Conventional treatment of metabolic alkalosis with sodium and potassium chloride relies mainly on renal suppression of acid excretion and enhancement of alkali excretion, as the respiratory response (hypoventilation) is not effective in protecting $\mathrm{pH} .{ }^{1}$ The renal corrective mechanisms are necessarily slow, and when metabolic alkalosis is likely, as in excessive loss of upper gastrointestinal contents, hepatorenal failure, severe shock states, and marked hypokalaemia from any cause (diuretics, diarrhoea, Conn's syndrome, and Cushing's disease), renal function is likely to be impaired.

A more physiological approach is to administer mineral acid to titrate excessive bicarbonate stores and effectively lower blood $\mathrm{pH}$. This has been given as ammonium chloride, which may cause encephalopathy when given parenterally, or as arginine monohydrochloride, a compound which supplies hydrochloric acid during its metabolism. Recently Abouna et $a l^{2}$ have successfully reversed severe metabolic alkalosis in a series of cases using intravenous hydrochloric acid. This must, however, be infused into a central vein.

The amount of mineral acid required can be calculated either from the extracellular chloride deficit ${ }^{3}$ :

$\mathrm{Cl}$ deficit $=(0.2 \times$ body weight in $\mathrm{kg}) \times(103-\mathrm{Cl}$ observed $)$ or from the bicarbonate excess ${ }^{4}$ :

hydrogen ion deficit $=(0.5 \times$ body weight in $\mathrm{kg}) \times$ $\left(\mathrm{HCO}_{3}\right.$ observed -24$)$

Abouna et al suggest that the amount of mineral acid given should be enough to provide $100 \%$ replacement of the chloride deficit and $50 \%$ replacement of the hydrogen ion deficit, this being given over 12-24 hours. ${ }^{2}$ The hydrochloric acid is given as an isotonic solution containing $150 \mathrm{ml}$ of $1-\mathrm{M} \mathrm{HCl}$ in one litre of sterile water, which gives $300 \mathrm{~mm}$ o of $\mathrm{H}^{+}$and $\mathrm{Cl}^{-}$per litre.

Patients with severe metabolic alkalosis are usually considerably volume contracted and will therefore also require isotonic saline with potassium supplements as judged by clinical state and serum electrolyte levels.

Although some workers feel that mineral acid should be used only when conventional treatment has failed, it seems that the use of intravenous hydrochloric acid, if carefully monitored by measurement of electrolytes and blood gases, is both effective and safe and provides a more physiological first-line approach to treating severe metabolic alkalosis; it should not be reserved solely as a "therapy of desperation."

I thank Dr A J King for permission to study one of the patients under his care and $\operatorname{Dr} A$ T Howarth for his help with the biochemistry.

1 Goldring, R M, et al, fournal of Clinical Investigation, 1968, 47, 188.

2 Abouna, G M, Aldrete, J A, and Starzl, T E, Surgery, 1974, 75, 194.

${ }^{3}$ Harken, A H, et al, Archives of Surgery, 1975, 110, 819.

4 Kassirer, J P, New England fournal of Medicine, 1974, 291, 773.

${ }^{5}$ Lancet, 1974, 1, 720.

St Luke's Hospital, Bradford BD5 ONA

$S$ E WILLIAMS, MB, MRCP, registrar in general medicine

\begin{tabular}{|c|c|c|c|c|c|c|c|c|c|c|c|c|}
\hline & & & \multicolumn{10}{|c|}{ Days after admission and time of estimation } \\
\hline & & & 1 & \multicolumn{2}{|c|}{2} & \multicolumn{3}{|c|}{3} & \multirow{2}{*}{$\begin{array}{c}4 \\
0900\end{array}$} & \multirow{2}{*}{$\frac{5}{0900}$} & \multirow{2}{*}{$\frac{6}{0900}$} & \multirow{2}{*}{$\frac{7}{0900}$} \\
\hline & & & 2300 & 1000 & 1500 & 0100 & 1000 & 1800 & & & & \\
\hline $\begin{array}{l}\mathrm{HCO}_{3}(\mathrm{mmol} / \mathrm{l}) \\
\mathrm{Cl}\left(\mathrm{mmol}^{\prime} / 1\right) \\
\mathrm{K}\left(\mathrm{mmol}^{\prime}\right) \\
\mathrm{Na}(\mathrm{mmol} / 1) \\
\mathrm{Urea}(\mathrm{mmol} / \mathrm{l}) \\
\mathrm{pH} \\
\mathrm{PCO}_{2}(\mathrm{kPa}) \\
\mathrm{HCO}_{3}(\mathrm{mmol} / \mathrm{l})\end{array}$ & $\begin{array}{l}\ldots \\
\ldots \\
\cdots \\
\cdots \\
\cdots \\
\cdots\end{array}$ & $\begin{array}{l}\cdots \\
\cdots \\
\cdots \\
\cdots \\
\cdots \\
\cdots\end{array}$ & $\begin{array}{c}>50 \\
<70 \\
2.6 \\
135 \\
21.5\end{array}$ & $\begin{array}{c}60 \\
64 \\
6.0 \\
141 \\
25 \cdot 0 \\
7 \cdot 54 \\
9 \cdot 4 \\
56 \cdot 5\end{array}$ & $\begin{array}{c}56 \\
65 \\
3 \cdot 4 \\
141 \\
31 \cdot 0\end{array}$ & $\begin{array}{c}36 \\
74 \\
3 \cdot 7 \\
139 \\
31 \cdot 5 \\
7 \cdot 51\end{array}$ & $\begin{array}{c}30 \\
90 \\
4 \cdot 3 \\
137 \\
30 \cdot 3 \\
7 \cdot 42 \\
6 \cdot 8 \\
30 \cdot 2\end{array}$ & $\begin{array}{c}26 \\
97 \\
3.6 \\
141 \\
29 \cdot 5\end{array}$ & $\begin{array}{c}20 \\
107 \\
4 \cdot 3 \\
143 \\
26 \cdot 0\end{array}$ & $\begin{array}{c}23 \\
107 \\
3.6 \\
143 \\
21 \cdot 2\end{array}$ & $\begin{array}{c}21 \\
102 \\
4 \cdot 3 \\
137 \\
17 \cdot 3\end{array}$ & $\begin{array}{c}24 \\
107 \\
3.8 \\
141 \\
13 \cdot 1\end{array}$ \\
\hline
\end{tabular}

